\title{
interview
}

\section{Worms and science}

\author{
An interview with Sydney Brenner, Distinguished Research Professor at The Salk Institute, La Jolla, USA, \\ and one of the winners of the 2002 Nobel Prize for Physiology and Medicine
}

EMBO reports: Have you ever thought about retiring now that you've been awarded the Nobel Prize?

Sydney Brenner: No, l've retired many times already. It's time to change again. What do you do if you retire? The interesting thing is to do research. It's better than anything else.

ER: In 1963, you wrote a letter to Max Perutz proposing to move beyond molecular biology. Why did you feel a need to switch your focus to developmental biology when molecular biology was still at such an early stage?

SB: It looked like the code was understood. We understood genes in principle, and how this information got turned into proteins. Of course, lots of details remained to be solved, but we thought that could easily be done by other people.

ER: Weren't you interested in the details?

SB: No, not once I could see there was a solution to the problem. And the problem that still has no solution is how genes specify the complex structures in organisms like ourselves. So that's what I proposed to move into. Ultimately, we'd like to understand how brains are built and how brains work. Of course, it was a modest beginning. Caenorhabditis elegans was chosen because of its convenience and finite size, and the fact that we could work on it in a laboratory.

The contact with the animal itself is very important for biologists because a lot of experimental research is remote. Francis Crick used to say "Sydney likes worms because they wriggle and you can watch them wriggling."

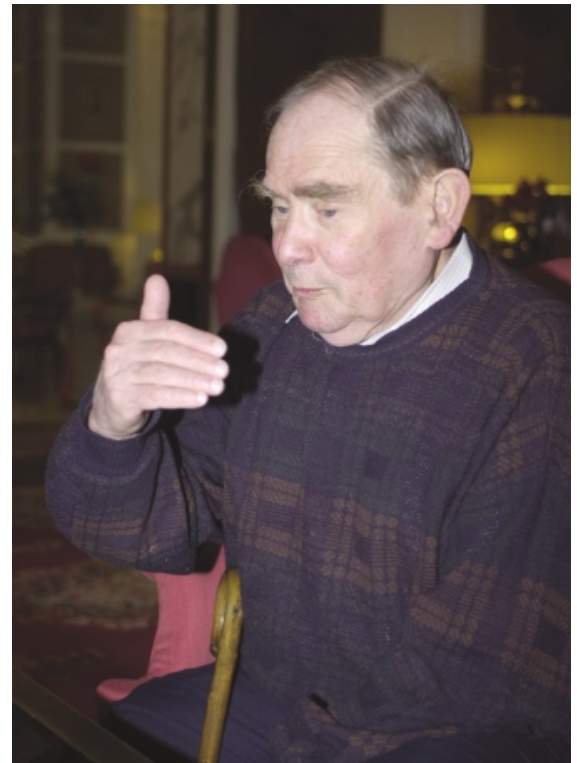

ER: At that time, people were already working on Drosophila.

SB: But that was too complicated. We wanted to determine the wiring diagram of the nervous system, so it had to be small and it had to be done by electron microscopy. Basically, the number of neurons in Drosophila is about 100,000, which means it's the geometrical average between a bacterium, with at most 1 neuron, and ourselves with $10^{10}$ neurons. And C. elegans with 300 neurons is again the geometric average between Escherichia coli and Drosophila, the square root of 100,000. It is a job you can actually tackle. That's why I chose it.

ER: Did you also work with other organisms in the beginning?

SB: I tried a lot of things, but after reading and looking at a lot of things I came to the conclusion that we needed an organism that laid eggs and whose eggs developed into animals. Nematodes were the most accessible then, the easiest to cultivate. Although C. elegans was the second one on the list of nematodes I collected, we didn't go back to it because when we first tried to fix it for electron microscopy, we couldn't. But later we understood why, and then of course it fixed beautifully. We then started to reconstruct the structure and tried to automate it and use computers, but it was 30 years too early. The technology didn't exist. Today you could probably do it, but to do the image processing then was just impossible. The only people who had this capacity must have been the CIA, because they had to fly over those bases in Cuba in 1963, and must have taken 2 million photographs and had them processed. But we weren't the CIA.

ER: Are you surprised about the success of C. elegans now?

SB: I'm not surprised, no. I'm pleased. I think it was a very good choice, and people have taken it and expanded it. I've been told that there is a new C. elegans laboratory every week somewhere in the world. It's almost like McDonalds. Now 400 labs are doing all kinds of things with it-social behaviour and ageing are very popular now. The contact with the animal itself is very important for biologists because a lot of experimental research is remote. Francis Crick used to say "Sydney likes worms because they wriggle and you can watch them wriggling."

ER: It's quite an unusual step from working at the molecular level to take a step 'backwards' and work on whole organisms.

SB: But you see, my previous training was in medicine. In fact, I was a skilled anatomist and I knew a lot about neuroanatomy, 


\section{Motivation is more important in science than anything else, because if you are motivated you can learn anything.}

embryology and histology. And I was a skilled microscopist as well, so in a sense, it was a step forwards because when we first tried to do embryology and study the brain, there just weren't the tools available. There wasn't the basic understanding that we now have through molecular biology. So it was time to go back. T.H. Morgan was an embryologist. He went into Drosophila because he thought he could study embryology, but he got tied up studying genetics and it took us 60-70 years to complete Morgan's deviation and get back to the real problems. It's a very different kind of culture from what you have now and all of us were amateurs. We never got a professional training. We could not, the subject did not exist. There was no academic way to study molecular biology. I think a lot of us who are self-taught in this field have carried that on. It's easy to teach yourself a new subject or a new technique. Everybody today believes they must go and do a course and study. It's a lot of nonsense.

ER: So you think this is an advantage, being an amateur as you say.

SB: I've always felt that talented amateurs are much better than professionals. None of the early people who came to work with me on C. elegans were trained in biology. John Sulston was an organic chemist, John White who did the anatomy was an electronic engineer, Graham Mitchison was a mathematician. I've never looked for background training. Motivation is more important in science than anything else, because if you are motivated you can learn anything.

ER: How do you see this current transition from hypothesis-based research to data generation?..

SB: It's nonsense. Total nonsense. I'm not only uninterested in it, I'm against it, because I think it's pretty mindless. It's false propagan$\mathrm{da}$, a false way of doing science. It's noninterventional. Of course, I'm not against collecting a lot of results at the same timeto me that's an experimental technique-but I'm not going to let the data think for me, because they can't. All you can find is maybe correlations, but correlations don't tell you causes and effects. If you know causes and effects, you can then calculate the unknown. That's what you want to do in science.

ER: You are one of the advisors to the Singaporean government for their plans to establish biotechnology. How do you see science in more developing countries?

SB: It's not just biotechnology, it's setting up the whole of biomedical research, which goes from very basic science to clinical medicine. Every country that has now reached a certain stage of development wants to become part of the knowledge-based economy. Everybody now knows that this is going to condition future development. It's not going to be limited by natural resources, it's going to be limited by what you know and how you apply it. Singapore has reached the stage where, unless they go towards a knowledgebased economy, there is no future. They've developed very fast over the last $30-40$ years and they are trying.

\section{ER: Why did you get involved in this?}

SB: I went out there in 1984 , I think, to advise them on biotechnology. They wanted to start an industry and I said, "You're wasting your time. What you need is to create science first." So they took that advice and set up an institute for cell and molecular biology that has done extremely well and has now generated PhDs. They now want to accelerate that generation of skilled people, because those people are needed to drive the engine of the economy.

ER: Do you think this could also happen in other less-developed countries, such as South Africa where you grew up?

\section{If you know causes and effects, you can then calculate the unknown. That's what you want to do in science.}

SB: South Africa has to do something to accelerate basic education. Everybody in Singapore is literate, whereas in South Africa even basic education has not expanded enough. Of course, the resources are limited, but they have the possibilities to do it. It is a country rich in natural resources, so it has that advantage, and I think it could have a future if they could just deal with the political and other structural problems there.

ER: But you never particularly wanted to get involved in South African science?

SB: I grew up there and I didn't go back until 1993 because I waited for the regime to change. When I went there, I gave some talks, but it's not the sort of thing I would do now at my age. The world says once you've reached 65 , forget it, and mostly they are right-for certain people it should be 35 rather than 65 . But basically what I think they need to do is accelerate science education at the school level, because you're not going to get anywhere until you do this. I did suggest that they should make a science high school and that the first teachers there should be part of a university. They could use the university faculty as the first teachers or graduate students, so they wouldn't have to wait decades while they trained teachers. Singapore just took $10 \%$ of its R\&D (research and development) budget for training a couple of thousand people to speed up that transition. Education is a very important part of policy, but of course, we all know that kids are not interested in science. In America, all people training for engineering come from Korea, Hong Kong and China, because to do science is not seen as something attractive by American youths.

\section{ER: Why do you think this is?}

SB: I think schools do a lot to knock it out of people. I was reading Richard Goldschmidt's autobiography. He grew up in Frankfurt, and as a high-school student, he worked in a museum, because in those days there was only one professor teaching at the university and no other positions. But the museums were doing research, and so there was somewhere you could go to spark your interest. I think a lot of that has been removed by teachers saying "this is the curriculum, these are the questions". Most children are interested in the natural world, but by the time they finish school, a lot of that has been removed. I also think that science is harder work than, let's say, sociology or cultural studies. People have learnt to choose the easiest path in life, and science requires dedication and stamina. Another thing is the anti-science, anti-technology mood that's growing up among people. Every time a scientific discovery is announced, immediately people say, "What harm can this do?" They don't say, 
"What good can this do?" There is a strong tendency to react against us, without people really understanding the nature of technology and its applications, and the scientists get blamed for everything. A lot needs to be done.

ER: You were a member of the Asilomar group, which discussed a moratorium on recombinant DNA technology in 1975. Regarding human cloning, do you think it's time for another moratorium?

SB: No, I'm very much against that. In fact, a moratorium is the source of all trouble. You need to say in advance under what conditions you will relax it. For example, now everybody says we will not alter the germline. But if I could give everyone a gene to protect them against, say, HIV infection, would I alter the germline or not? I think there are conditions. 'Never' is too strong a word. One of the difficulties is that it's easy to create a moratorium, and the public thinks everybody is acting responsibly, but of course when you need to dismantle it then you have problems, because people will say, "What have you learnt in the last six months that causes you to think otherwise?" Of course, everybody says there's a moratorium against cloning people. First of all, we can't clone people. There's a difference between chastity and impotence: they both have the same result, but the reasons are different. We are impotent in this thing, so it's very easy to be chaste. I was once at a press meeting where a reporter got up and began to yell at me, "The trouble with you scientists is that you just want to make people." I said "Look, I can think of much cheaper and much more pleasant ways of making people than working in a laboratory and trying to do it by genetic engineering. It's very expensive."

...it's easy to create a moratorium,
and the public thinks everybody is
acting responsibly, but of course
when you need to dismantle it,
then you have problems...

ER: When Joe Tsien at Princeton created Doogie, the smart mouse, he was bombarded with phone calls, faxes and e-mails from parents who wanted to have smart children. What do you say if the public comes to you and says, "We want this gene"?

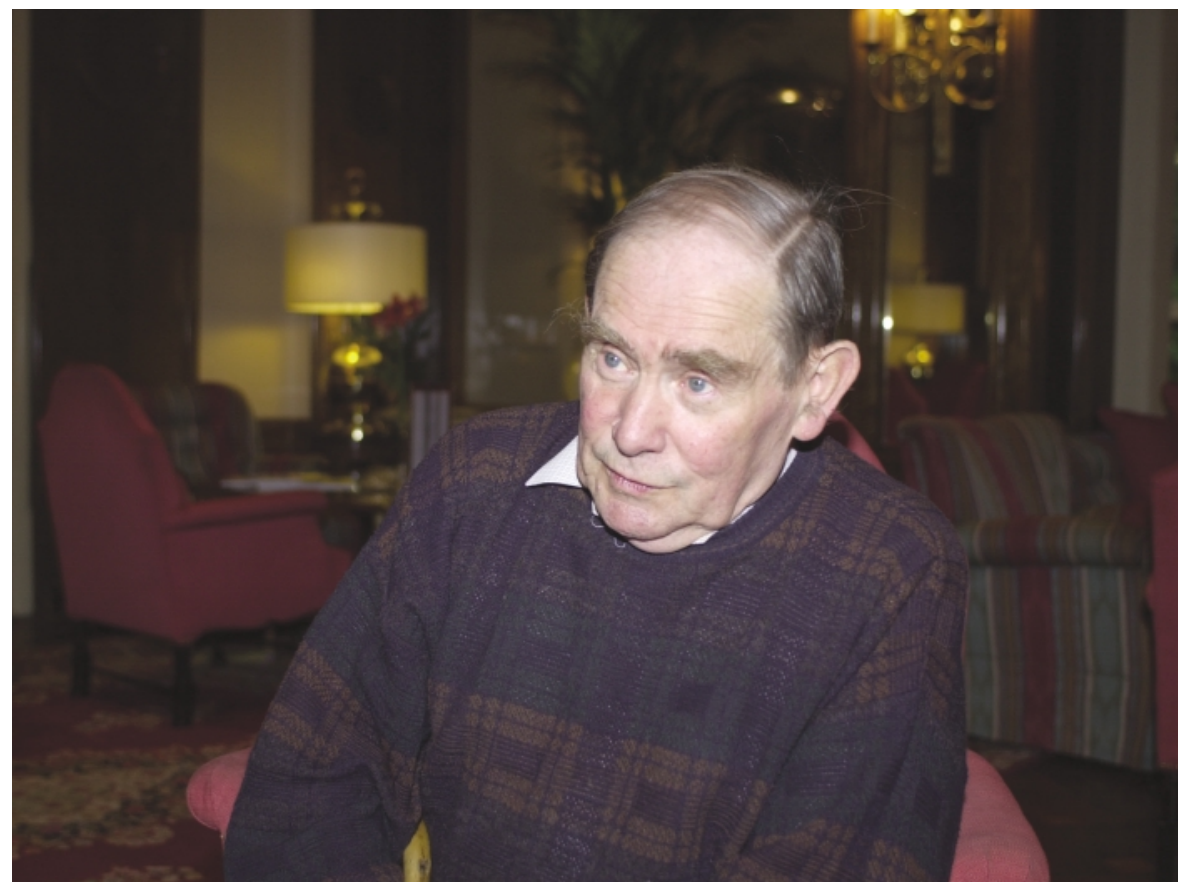

SB: If a child were to say, "I want to be smart", you just have to say, "You chose the wrong parents." There isn't such a gene, it so happened it made the mouse smarter, but the mouse may actually die prematurely of being so smart. Then you have the choice of being smart and having a hectic life, or being slightly dull and living longer. Maybe the product of smartness and time is constant. We also have a very naive view of genetic determinism. We have an idea that there's a gene for characteristics, a gene for homosexuality, a gene for alcoholism, a gene for criminality. There isn't. When the chimpanzee genome and the human genome are sequenced, people say as a joke, "There'll be one extra gene in the human that will be the gene for language, called the Chomsky gene." It could be the other way around. The extra one could be in the chimpanzee because they have learnt that it is disadvantageous to talk. It gets you into trouble. So they have a language suppressor gene. Then of course we'd call it the Chimpsky gene. I think we have just too naive a view of this.

ER: You have often been introduced as the greatest scientist who never won the Nobel Prize. That changed a few weeks ago.

SB: I'll have to change it to "who never won his first Nobel Prize". The Nobel Prize is given for a discovery, and if you don't make discoveries, you don't get the Nobel Prize.
Einstein didn't get it for relativity, he got it for something trivial, he got it for the photoelectric effect and not for his fundamental work in theoretical physics. It's rather silly. When you're my age, this just becomes a nuisance, because it just takes up time. Time is my most valuable commodity at this point, and I shouldn't be wasting it talking to journalists. I think there is a fourth winner of the prize, and that's $C$. elegans. That's who should get the prize. They should invert Nobel and then it would become Lebon, and the Lebon prize should go to the animal. The prize that I was very pleased to get was the Jeantot because they gave me a research fund, and I could use this.

ER: But it's the same with the Nobel Prize.

SB: No, it's not a research fund because it's believed, at least by the US tax authorities, to be a stipend. I wish they would give it to me as a research prize. But I'll have to share it with George Bush, and he didn't do any work to deserve anything. But it's good to have the work recognized in this way.

ER: Professor Brenner, thank you for the interview.

\section{The interview was conducted by}

Holger Breithaupt and Susan R. Owens

doi:10.1038/sj.embor.embor780 